\title{
Standardization of Phyllanthus niruri and Sonchus arvensis as Components of Scientific Jamu
}

\author{
Nikmatul Ikhrom Eka Jayani ${ }^{1}$, Alfian Hendra Krisnawan¹, Nina Dewi Oktaviyanti1 , Kartini1,2, \\ ${ }^{1}$ Department of Pharmaceutical Biology, Faculty of Pharmacy University of Surabaya, Indonesia \\ ${ }^{2}$ Centre for Information and Development of Traditional Medicine, University of Surabaya, Indonesia
}

\begin{abstract}
Saintifikasi Jamu, or the scientific investigation of Jamu, is an evidence-based process to ensure the safety and efficacy of herbal medicine through health service research. Jamu has been empirically explored as a composition of various crude drugs, hence called as Scientific Jamu. Phyllanthus niruri and Sonchus arvensis are two of the 30 medicinal plants processed into Scientific Jamu. Components of the Scientific Jamu are standardized to ensure that these materials meet the predefined quality. This study was aimed to determine the specific parameters (macroscopic, microscopic, total flavonoid content, water-soluble extract content, and ethanol-soluble extract content) and non-specific parameters (loss on drying, total ash content, and acid insoluble ash content) of Phyllanthus niruri and Sonchus arvensis collected from Batu, Tawangmangu, and Bogor. The methods of the determination referred to the Indonesian Herbal Pharmacopoeia $1^{\text {st }}$ Edition (2008). The results showed that Phyllanthus niruri and Sonchus arvensis from the three places did not meet the standard requirement.
\end{abstract}

Keywords: Standardization; Phyllanthus niruri; Sonchus arvensis; Scientific Jamu

\section{INTRODUCTION}

Jamu is Indonesian indigenous herbal medicine that has been used empirically to prevent and treat various diseases. The Indonesian government has been developing Jamu into Standardized Herbal Medicine and Phytopharmaca to provide evidence of its safety and efficacy scientifically. This effort includes a strategy called "Saintifikasi Jamu" (i.e., scientific investigation of indigenous herbal medicine) to create the Scientific Jamu by analyzing the long-standing use of jamu through health service-based research. The naming and procedures of Saintifikasi Jamu are specified in the Regulation of the Minister of Health No. 003/I/MENKES/2010 (Purwadianto et al., 2017). There have been seven formulas of Scientific Jamu made of a mixture of various preselected crude drugs that can be found in conventional jamu. The examples include Phyllanthus niruri (Indonesian: meniran) and Sonchus arvensis (Indonesian: tempuyung) (Figure 1) (Triyono et al., 2016), which are two of the focal 30 medicinal plants in the research and development program of traditional medicines from raw materials supported by the Indonesian Ministry of Health (MENKES RI, 2013).

The Saintifikasi Jamu program is designed to increase the availability, safety, efficacy of herbal medicine. Also, it intends to promote using herbal medicine in both self-medication and treatments in primary health care facilities (MENKES RI, 2010).

*Corresponding author : Kartini

Email : kartini@staff.ubaya.ac.id
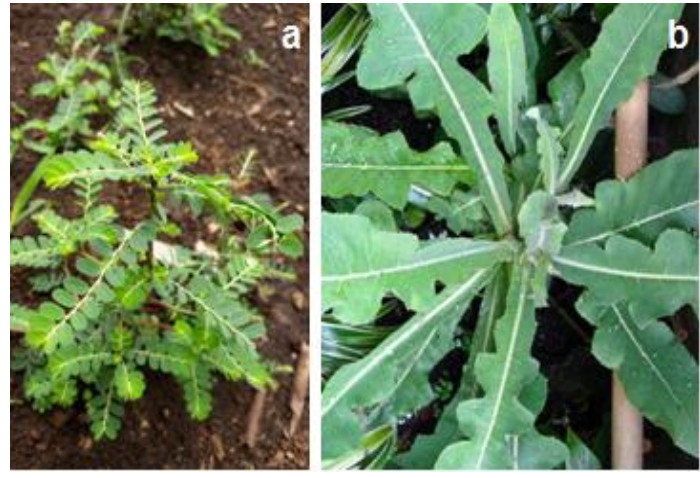

Figure 1. Phyllanthus niruri (a) and Sonchus arvensis (b)

The quality of crude drug materials is a prerequisite for ensuring the safety and efficacy of herbal medicines. However, physicians expecting to participate in this program are still faced with a significant problem; that is, the availability of qualified and standardized crude drugs. B2P2T00T Tawangmangu has been the only major supplier of Scientific Jamu. Therefore, various efforts to support the sustainable availability of qualified crude drugs from different regions in Indonesia are welcome, including the cultivation and standardization process.

Standardization of herbal drugs is a process to confirm the identity, quality, and purity of herbal materials (Jayani et al., 2020). It serves to ensure the quality of herbs used as raw materials in herbal medicinal products by comparing it with the 
standard quality of crude drugs issued in the Indonesian Herbal Pharmacopoeia $1^{\text {st }}$ edition (DEPKES RI, 2008). In this context, the quality of the crude drugs depends on many factors, such as environment, soil, climate, seed quality, harvest, and preparation of crude drug that includes drying method and storage condition (DEPKES RI, 2008; WHO, 2011). In this study, we standardized two of six plant materials used in Scientific Jamu as antihyperuricemic medicine, namely, Phyllanthus niruri and Sonchus arvensis collected from three different geographical locations in Indonesia. Both plants were standardized to ensure that the resulting crude drugs met all of the quality parameters listed in the Indonesian Herbal Pharmacopoeia $1^{\text {st }}$ edition (DEPKES RI, 2008).

\section{METHODOLOGY}

\section{Materials and equipment}

Phyllanthus niruri and Sonchus arvensis samples were collected from three institutions in Indonesia in March of 2018. (1) UPT Materia Medica Batu (the Province of Jawa Timur) is located at an altitude of $\pm 875 \mathrm{~m}$ above the sea level with a temperature of $\pm 20-25^{\circ} \mathrm{C}$. (2) Biopharmaca Cultivation Conservation Unit, Studies Center for Tropical Biopharmaca IPB Bogor (the Province of Jawa Barat) is situated at $\pm 145-400 \mathrm{~m}$ above the sea level with a temperature of $\pm 25-33^{\circ} \mathrm{C}$. (3) B2P2T00T Tawangmangu in Karanganyar (the Province of Jawa Tengah) is located at $\pm 1200 \mathrm{~m}$ above the sea level with a temperature of \pm 22 $31^{\circ} \mathrm{C}$. These institutions were also responsible for determining the crude drugs of both plants. The chemicals used in the study were chloral hydrate (Merck), $\mathrm{HCl}$ (Merck), chloroform (Mallinckrodt), ethanol 96\% (Merck), $\mathrm{H}_{2} \mathrm{SO}_{4}$ (Merck), $\mathrm{NaNO}_{2}$ (Merck), $\mathrm{AlCl}_{3}$ (Merck), $\mathrm{NaOH}$ (Merck), $\mathrm{CH}_{3} \mathrm{CO}_{2} \mathrm{~K}$ (Merck), quercetin (Sigma), and demineralized water.

Meanwhile, the research equipment included analytical balance (Ohaus), oven (Memmert), moisture content balance (Mettler Toledo), desiccator (Duran), binocular microscopes (Olympus), furnace (Memmert), ultrasonic cleaner (Branson), spectrophotometer (Shimadzu), and laboratory glassware.

\section{Preparation of powdered crude drugs}

The sampled crude drugs of Phyllanthus niruri and Sonchus arvensis were ground to powders using a blender and then sifted with a 40mesh sieve.

\section{Macroscopic and microscopic tests}

The macroscopic test was carried out to observe the organoleptic properties directly from the shape, color, smell, and taste. Meanwhile, in the microscopic test, the powdered crude drugs were placed on an object-glass, added with chloral hydrate, covered with a cover glass, and heated quickly with low heat at a distance of $\pm 8 \mathrm{~cm}$ to spiritus flame. Afterward, the fragments of phyllanthus niruri and Sonchus arvensis were observed under a microscope with 10x40 magnification (WHO, 1998; DEPKES RI, 2008).

\section{Determination of total flavonoids}

The total flavonoid content was determined by the spectrophotometric method described in Amessis-Ouchemoukh et al. (2014). The crude drugs were first extracted with $96 \%$ ethanol. One $\mathrm{ml}$ of the sample solution was put in a $10 \mathrm{ml}$ volumetric flask, then added with $4 \mathrm{ml}$ of demineralized water and $0.3 \mathrm{ml}$ of $5 \% \mathrm{NaNO}_{2}$, left for 5 minutes, and added with $0.3 \mathrm{ml}$ of $10 \% \mathrm{AlCl}_{3}$. At the 6th minute, $2 \mathrm{ml}$ of $1 \mathrm{M} \mathrm{NaOH}$ was added, followed by demineralized water up to exactly 10.0 $\mathrm{ml}$. The absorbance of each sample solution was read using a spectrophotometer at $400.2 \mathrm{~nm}$. The concentrations of the total flavonoids were calculated and expressed as g quercetin equivalent (QE)/g dry weight (DW).

\section{Determination of water- and ethanol-soluble extract}

Five gram of crude drug powder was placed in a clogged Erlenmeyer and macerated with 100 $\mathrm{ml}$ of water (saturated with $\mathrm{CHCl}_{3}$ ) or ethanol for 6 hours, shaken frequently, and allowed to stand for 18 hours. Afterward, the extract produced was quickly filtered and poured into a $100.0 \mathrm{ml}$ volumetric flask. Twenty $\mathrm{ml}$ of this extract was transferred to a porcelain cup and then evaporated until dry, and then the residue was heated using an oven at $105^{\circ} \mathrm{C}$ to constant weight. The soluble extract was calculated in $\mathrm{g}$ per $\mathrm{g}$ of air-dried material (DEPKES RI, 2008).

\section{Determination of loss on drying (LOD)}

About 1-2 $\mathrm{g}$ of the crude drug powder was placed in crucible porcelain and dried at $105^{\circ} \mathrm{C}$ for 60 minutes. Then, the crucible porcelain was moved into a desiccator (until room temperature). This process was repeated until the constant weight was achieved. LOD was expressed as g per g of air-dried material (DEPKES RI, 2008).

\section{Determination of total ash}

About 2-4 g of the crude drug powder was placed in crucible porcelain and ignited by gradually increasing the heat temperature to $500-600^{\circ} \mathrm{C}$ until ashes were formed. Then, the ashed powder was allowed to cool in a desiccator. 


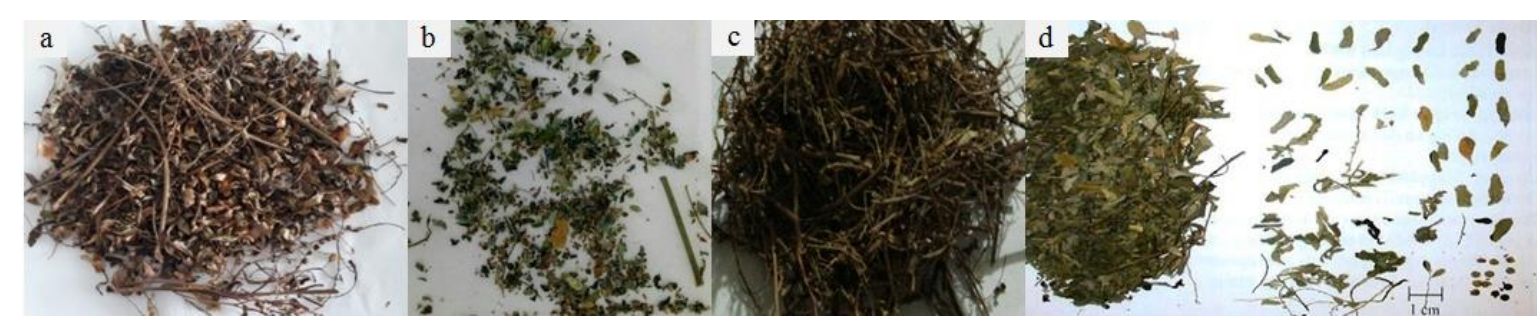

Figure 2. The macroscopic profiles of Phyllanthus niruri from Batu (a), Tawangmangu (b), and Bogor (c) and the standard macroscopic appearance $(\mathrm{d})$

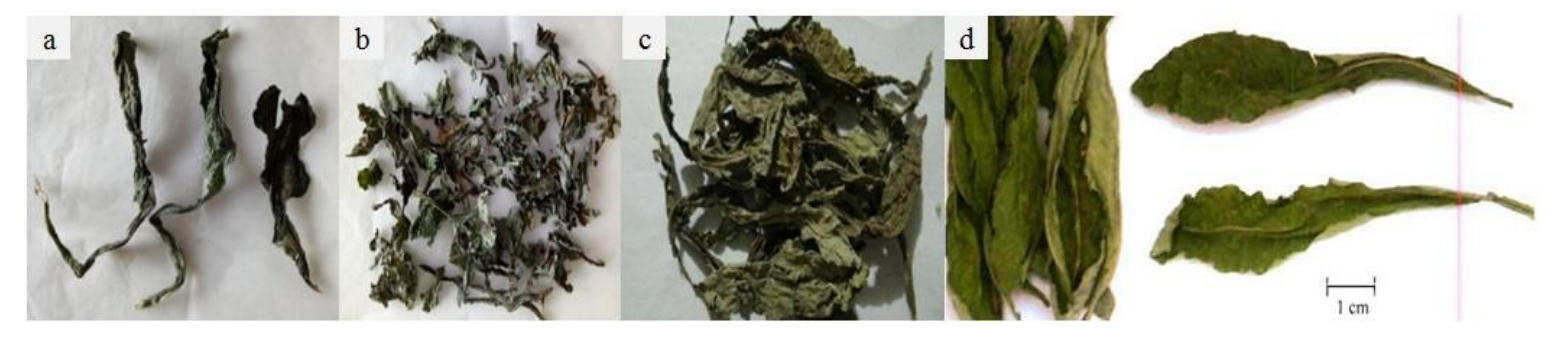

Figure 3. The macroscopic profiles of Sonchus arvensis from Batu (a), Tawangmangu (b), and Bogor (c), and the standard macroscopic appearance (d)

In the event of failed ash formation, the residue was moistened with $\pm 2 \mathrm{ml}$ of water or a saturated solution of ammonium nitrate $\mathrm{R}$ and then dried on a water-bath and, subsequently, a hot-plate to constant weight. The crucible porcelain was moved into a desiccator for 30 minutes. This process was repeated until a constant weight was achieved. The total ash content was calculated in g per $g$ of airdried material (DEPKES RI, 2008).

\section{Determination of acid-insoluble ash}

The product of the previous procedure (i.e., determination of the total ash content) was added with $25 \mathrm{ml}$ of hydrochloric acid $(\sim 70 \mathrm{~g} / \mathrm{l}) \mathrm{TS}$, covered with a cover-glass, and boiled gently for 5 minutes. The cover-glass was rinsed with $5 \mathrm{ml}$ of hot water, and this remnant was added to the crucible. The insoluble matter was collected on an ashless filter paper and washed with hot water until the filtrate was neutral. Afterward, filter paper containing the insoluble matter was transferred to the first crucible and dried on a hotplate to constant weight. Then, the acid-insoluble ashed powder was allowed to cool in a desiccator for 30 minutes. The content of the acid-insoluble ash was calculated in $g$ per $g$ of air-dried material (DEPKES RI, 2008).

\section{Data analysis}

The evaluation results of all parameters were compared to the quality standards of crude drugs, as listed in the Indonesian Herbal Pharmacopoeia $1^{\text {st }}$ edition (DEPKES RI, 2008).

\section{RESULT AND DISCUSSION}

The macroscopic properties of the crude drugs

Macroscopic characterization is the first step to establish the identity, purity, and quality of a crude drug. In this study, visual inspection, recommended as the most straightforward and quickest means, was followed by further tests to justify whether or not Phyllanthus niruri and Sonchus arvensis satisfied the requirements set in the Indonesian Herbal Pharmacopoeia $1^{\text {st }}$ edition (DEPKES RI, 2008). In general, Phyllanthus niruri macroscopically appears as an herb with a round stem and small oval-shaped leaf with a size of 2.5-5 mm. The crude drug is brownish-green and has a specific odor and bitter taste. The macroscopic details of the Phyllanthus niruri samples from Batu, Tawangmangu, and Bogor are presented in Figure 2.

Meanwhile, Sonchus arvensis leaves are brownish-green, odorless, and generally folded or rolled up and has a slightly bitter taste. They are oval-shaped or lanceolate with irregular notched, acute base, irregular margin, and rougher and paler on the upper side. The macroscopic details of the $S$. arvensis leaves collected from Batu, Tawangmangu, and Bogor are presented in Figure 3. As seen in Figures 2 and 3, the leaf samples of Phyllanthus niruri and Sonchus arvensis are 

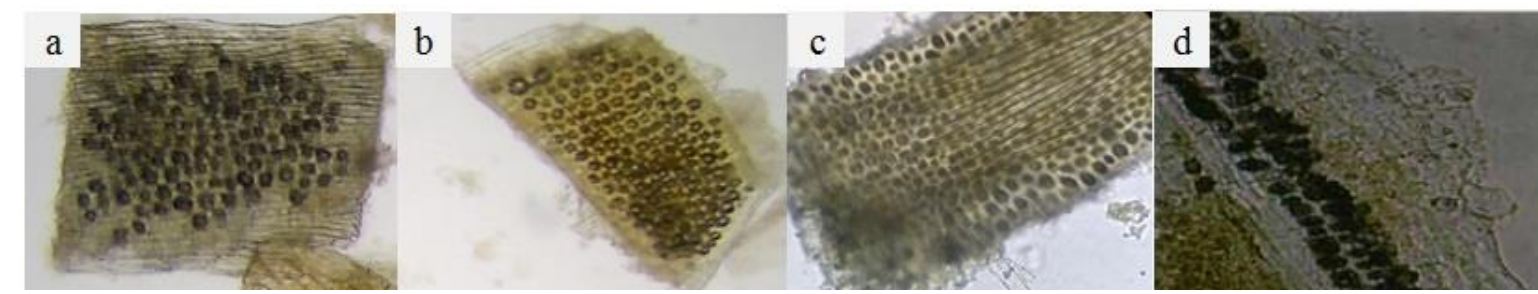

Figure 4. Upper epidermal fragments with rosette-shaped calcium oxalate crystals, 400x magnification: Phyllanthus niruri from Batu (a), Tawangmangu (b), Bogor (c), and the standard (d)

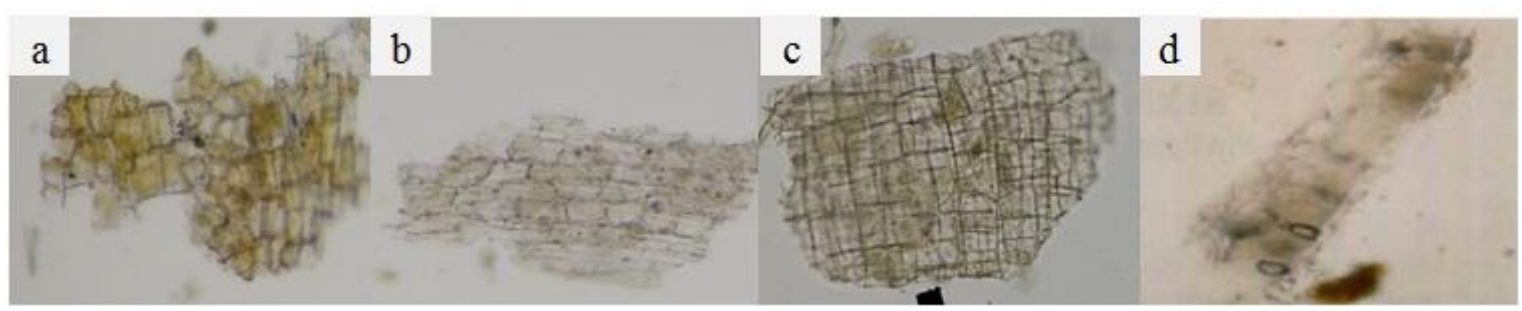

Figure 5. Upper epidermal fragments with prismatic calcium oxalate crystals in the palisade, 400x magnification: Phyllanthus niruri from Batu (a), Tawangmangu (b), Bogor (c), and the standard (d)

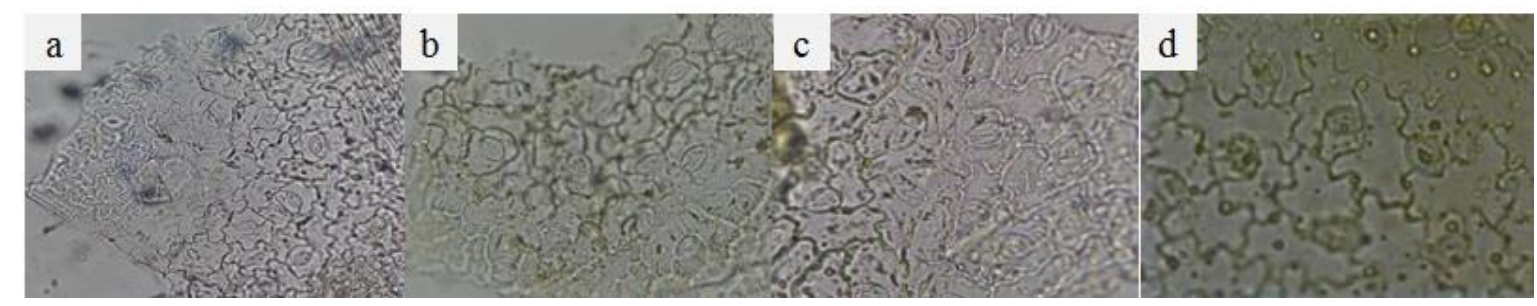

Figure 6. Fragments of the lower epidermis with stomata, 400x magnification: Phyllanthus niruri from Batu (a), Tawangmangu (b), Bogor (c), and the standard (d)

macroscopically consistent with the standards set in the Indonesian Herbal Pharmacopoeia $1^{\text {st }}$ edition (DEPKES RI, 2008).

\section{The microscopic properties of the crude drugs}

Microscopic profiles are useful in determining powdered materials and their plant sources. Although microscopic examination alone cannot always provide complete identification, it often produces valuable supporting evidence when used in conjunction with other analytical methods. The results showed that microscopically the sampled Phyllanthus niruri had adaxial epidermis with rosette-shaped calcium oxalate crystals and palisade tissue (in the adaxial epidermis) with prismatic calcium oxalate crystals, abaxial epidermis with stomata, pericarpium, and tangential bodies (Figures 4-8).

The Sonchus arvensis leaf samples were microscopically identified from their glandular trichomes, abaxial epidermis, anisocytic stomata, transport systems, and adaxial epidermis (Figures 9-12).
As seen in Figures 4-12, the microscopic features of the Phyllanthus niruri and Sonchus arvensis samples collected from the three regions meet the requirements of the Indonesian Herbal Pharmacopoeia $1^{\text {st }}$ edition (DEPKES RI, 2008). These results confirm that the identities of the sampled crude drugs are correct, i.e., that they come from Phyllanthus niruri and Sonchus arvensis, not from other plants.

\section{Total flavonoids content}

Phyllanthus niruri contain various active phytochemicals, such as flavonoids, alkaloids, terpenoids, lignans, polyphenols, tannins, coumarins, and saponins. Rutin, quercetin, quercitrin, astragalin, and catechin are the main flavonoids found in this plant (Bagalkotkar et al., 2006). Moreover, different types of phytoconstituents have also been detected in Sonchus arvensis, including steroids, phenols, and flavonoids. Myricetin, quercetin, kaempferol, and apigenin are some of the flavonoids found in this medicinal plant (Xia et al., 2010; Seal et al., 2016). 

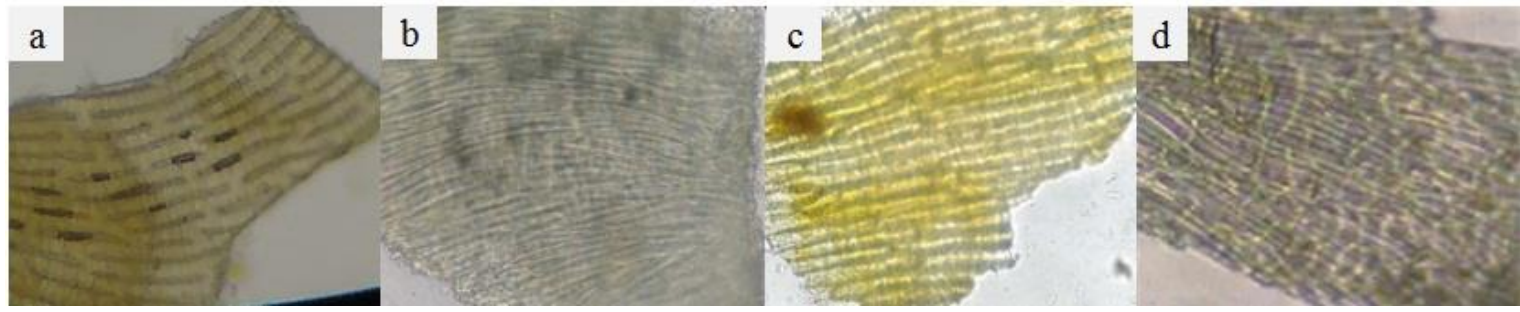

Figure 7. Pericarpium fragments, 400x magnification: Phyllanthus niruri from Batu (a), Tawangmangu (b), Bogor (c), and the standard (d)

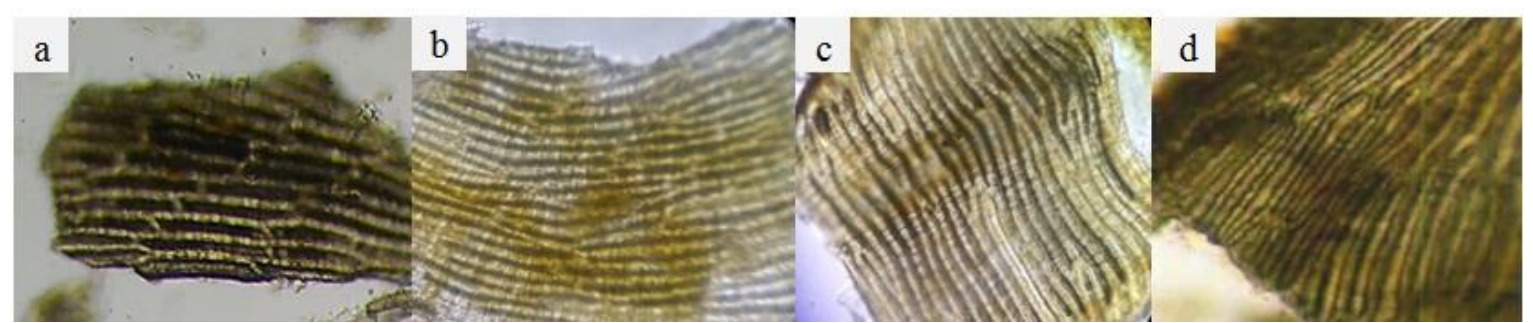

Figure 8. The tangential appearances of spermoderm fragments, 400x magnification: Phyllanthus niruri from Batu (a), Tawangmangu (b), Bogor (c), and the standard (d)

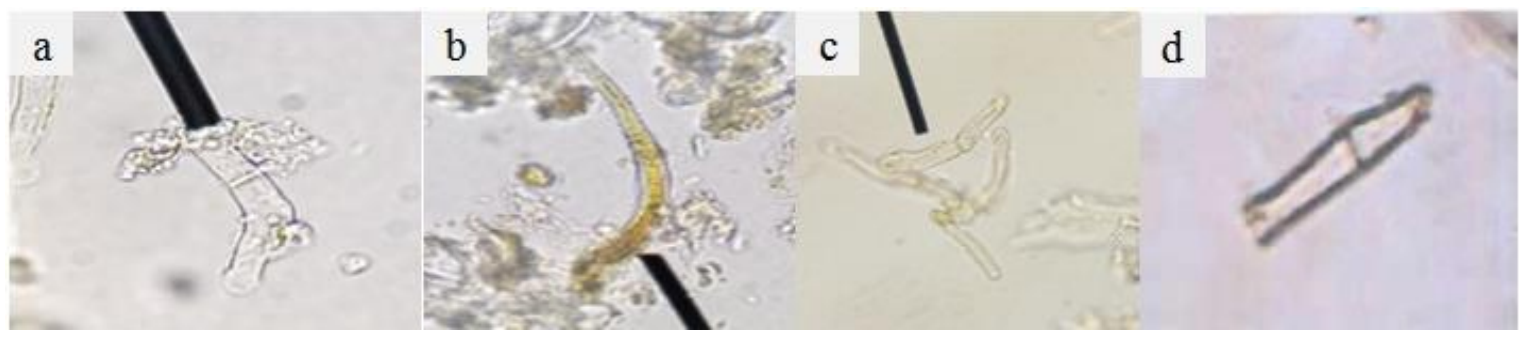

Figure 9. Glandular hair fragments, 400x magnification: Sonchus arvensis from Batu (a), Tawangmangu (b), Bogor (c), and the standard (d)

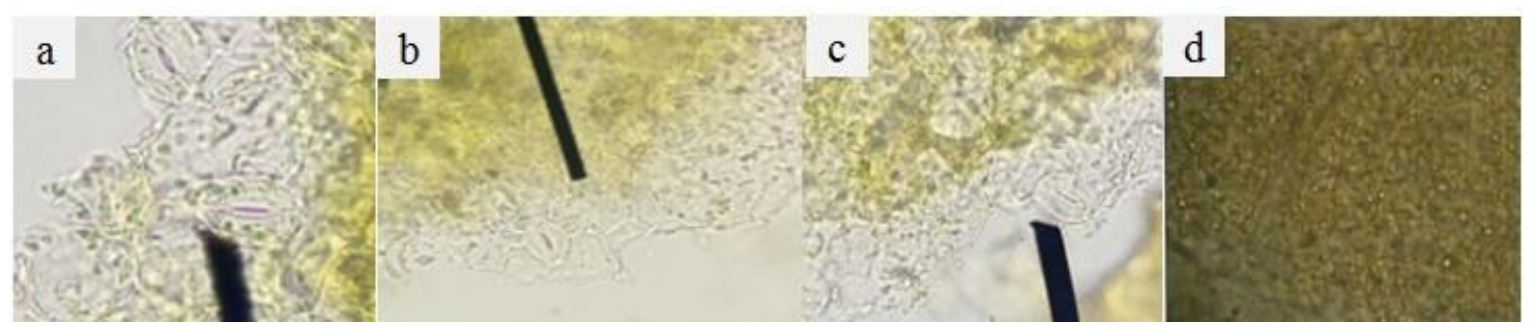

Figure 10. Lower epidermal fragments with anisocytic stomata, 400x magnification: Sonchus arvensis from Batu (a), Tawangmangu (b), Bogor (c), and standard (d)

Many studies (e.g., Tapas et al., 2008; Kumar et al., 2013) suggest that flavonoids possess antioxidative, free radical scavenging, hepatoprotective, anti-inflammatory, and anticancer activities and are well-known for its function in coronary heart disease preventions. Meanwhile, some flavonoids exhibit potential antiviral, antiallergic, antithrombotic, antispasmodic, and immunomodulatory capacities. Therefore, pharmacopeias, including Indonesian
Herbal Pharmacopoeia $1^{\text {st }}$ edition (DEPKES RI, 2008), typically use this class of compound as one of the chemical markers or parameters in standardization. Table I shows the total flavonoid content of Phyllanthus niruri and Sonchus arvensis, as determined by UV-Vis spectrophotometry.

Based on Table I, the total flavonoid contents of Phyllanthus niruri sampled from the three regions did not meet the requirements of the Indonesian Herbal Pharmacopoeia $1^{\text {st }}$ edition 


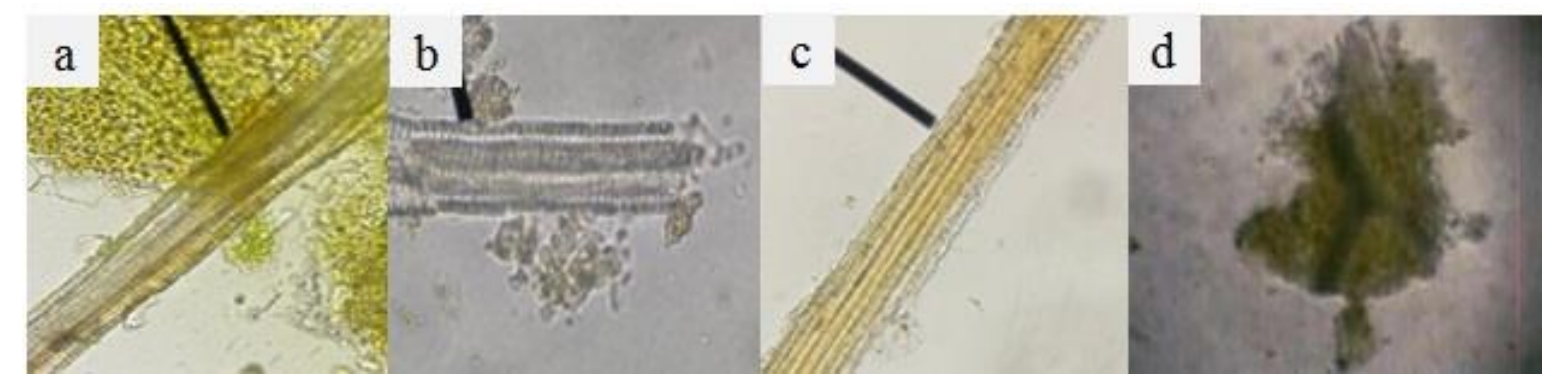

Figure 11. Fragments of the transport system, 400x magnification: Sonchus arvensis from Batu (a), Tawangmangu (b), Bogor (c), and the standard (d)



Figure 12. Upper epidermal fragments, 400x magnification: Sonchus arvensis from Batu (a), Tawangmangu (b), Bogor (c), and the standard (d)

Table I. The total flavonoid content of Phyllanthus niruri and Sonchus arvensis

\begin{tabular}{lcccc}
\hline \multirow{2}{*}{ Origin of samples } & \multicolumn{2}{c}{ Total flavonoids (\%QE) } & \multicolumn{2}{c}{ The standard total flavonoids (\%) } \\
\cline { 2 - 5 } & Phyllanthus niruri & Sonchus arvensis & Phyllanthus niruri & Sonchus arvensis \\
\hline Batu & $0.42 \pm 0.02$ & $0.49 \pm 0.02$ & $0.9^{*}$ & $0.06^{* *}$ \\
Tawangmangu & $0.36 \pm 0.04$ & $0.39 \pm 0.01$ & & \\
Bogor & $0.36 \pm 0.04$ & $0.39 \pm 0.01$ & & \\
\hline
\end{tabular}

Notes: Five replications for each parameter measured; *expressed as \%Quercetin Equivalent; **expressed as \%Luteolin Equivalent

(DEPKES RI, 2008). On the contrary, the Sonchus arvensis samples from the tree regions contained total flavonoids upwards of, or consistent with, the minimum requirement of the Indonesian Herbal Pharmacopoeia $1^{\text {st }}$ edition (DEPKES RI, 2008).

Water- and ethanol-soluble extracts, loss on drying, total ash content, and acid-insoluble ash content

In addition to macroscopic-microscopic profiles and total flavonoid content, water- and ethanol-soluble extracts were also examined as specific parameters (Tables II and III). Total extract content correlates with the concentration of chemical compounds dissolved in certain solvents. This parameter provides initial information on the total amounts of the chemical compounds in an herbal material (DEPKES RI, 2000).

The results showed that the water- and ethanol-soluble extracts of the Phyllanthus niruri leaves from the three origins were 12.19-17.54\% and $8.79-13.55 \%$, respectively. Meanwhile, the water- and ethanol-soluble extracts of Sonchus arvensis collected from the three origins were $12.91-14.56 \%$ and $8.05-11.47 \%$, respectively. These figures mean that in both crude drugs, the concentrations of water-soluble extracts are higher than their ethanol counterparts. From this finding, the Phyllanthus niruri and Sonchus arvensis crude drugs were predicted to contain high levels of polar compounds. Unfortunately, some of their water- and ethanol-soluble extracts did not meet the requirements of the Indonesian Herbal Pharmacopoeia $1^{\text {st }}$ edition (DEPKES RI, 2008), which is attributable to, for instance, the age of the plant, harvest time, climate, and geographical location.

Loss on drying (LOD) refers to the residual substances produced in drying at $105^{\circ} \mathrm{C}$ for 30 minutes or until a constant weight is achieved. 
Table II. The water- and ethanol-soluble extracts, loss on drying, total ash, and acid-insoluble ash of Phyllanthus niruri

\begin{tabular}{lcccc}
\hline \multirow{2}{*}{ Parameters } & \multirow{2}{*}{ Standards } & \multicolumn{3}{c}{ Origin of samples } \\
\cline { 3 - 5 } & & Batu & Tawangmangu & Bogor \\
\hline Water-soluble extract (\%) & NLT 16.0 & $12.19 \pm 0.03$ & $17.54 \pm 0.44^{*}$ & $13.20 \pm 0.40$ \\
Ethanol-soluble extract (\%) & NLT 8.0 & $8.79 \pm 0.93^{*}$ & $13.55 \pm 0.18^{*}$ & $8.96 \pm 0.59^{*}$ \\
Loss on drying (\%) & NMT 14 & $9.21 \pm 0.17^{*}$ & $8.65 \pm 0.57^{*}$ & $7.62 \pm 0.38^{*}$ \\
Total ash (\%) & NMT 7.2 & $7.93 \pm 0.21$ & $8.26 \pm 0.58$ & $7.83 \pm 0.98$ \\
Acid-insoluble ash (\%) & NMT 1.2 & $1.08 \pm 0.20^{*}$ & $1.08 \pm 0.12^{*}$ & $0.51 \pm 0.05^{*}$ \\
\hline
\end{tabular}

Notes: Five replications for each parameter measured; NLT: not less than; NMT: not more than

*meet the quality standards set in the Indonesian Herbal Pharmacopoeia $1^{\text {st }}$ edition (DEPKES RI, 2008)

Table III. The water- and ethanol-soluble extracts, loss on drying, total ash, and acid-insoluble ash of Sonchus arvensis

\begin{tabular}{lcccc}
\hline & \multicolumn{3}{c}{ Standard } & \multicolumn{3}{c}{ Origin of sample } \\
\cline { 3 - 5 } \multicolumn{1}{c}{ Parameters } & $\begin{array}{c}\text { Farmakope } \\
\text { Herbal Indonesia } \\
\text { Edisi I, 2008) }\end{array}$ & Batu & Tawangmangu & Bogor \\
\hline Water-soluble extract (\%) & NLT 17.1 & $14.56 \pm 0.63$ & $12.91 \pm 1.15$ & $17.65 \pm 0.93^{*}$ \\
Ethanol-soluble extract (\%) & NLT 19.4 & $8.05 \pm 0.31$ & $11.47 \pm 0.74$ & $11.10 \pm 0.16$ \\
Loss on drying (\%) & NMT 10 & $10.36 \pm 0.24$ & $8.22 \pm 0.12^{*}$ & $7.82 \pm 0.32^{*}$ \\
Total ash (\%) & NMT 15.4 & $17.08 \pm 0.34$ & $18.45 \pm 0.14$ & $17.75 \pm 0.47$ \\
Acid-insoluble ash (\%) & NMT 0.2 & $2.58 \pm 1.23$ & $2.38 \pm 0.52$ & $3.03 \pm 0.45$ \\
\hline
\end{tabular}

Notes: Five replications for each parameter measured; NLT: not less than; NMT: not more than

* meet the quality standards set in the Indonesian Herbal Pharmacopoeia $1^{\text {st }}$ edition (DEPKES RI, 2008)

This test aims to determine the maximum limits (in ranges) of the number of compounds lost in the drying process, for example, the loss water and other volatile compounds like essential oils (DEPKES RI, 2008; 2010). The Phyllanthus niruri and Sonchus arvensis sampled from three Indonesian regions met the standards for LOD, except for the S. arvensis leaf samples from Batu. In crude drugs, high moisture content facilitates the growth of microbes during storage, leading to hydrolysis and, subsequently, the decomposition of chemical compounds (Krisyanella et al., 2017).

Total ash content measures the total amount of material remaining in powdered crude drugs after ignition. It includes "physiological ash" derived from the plant tissue itself and "nonphysiological ash", which is the residue of the extraneous matter (e.g., sand and soil) adhering to the plant surface. As for acid-insoluble ash content, it refers to the residues obtained after boiling the total ash with dilute hydrochloric acid and igniting the remaining insoluble matters. It measures the amount of silica present in a crude drug, especially in the forms of sand and siliceous earth.

Table II shows that the total ash content of Phyllanthus niruri from the three areas of origin did not fulfill the requirement, but the opposite was true for the acid-insoluble ash content. These results indicate that the high total ash content of the Phyllanthus niruri is composed of physiological ash. As seen in Table III, both total and acid-insoluble ash contents of Sonchus arvensis did not satisfy the standard. In other terms, the physiological and non-physiological ash contents of this crude drug are categorically high. The high content of non-physiological ash is potentially caused by imperfect washing processes.

\section{CONCLUSION}

The medicinal properties of the Phyllanthus niruri and Sonchus arvensis samples collected from Batu, Tawangmangu, and Bogor do not meet the requirements set in the Indonesian Herbal Pharmacopoeia $1^{\text {st }}$ edition (DEPKES RI, 2008). Before use, any results representing information on the origin of the plant materials and the crude drugs must be scrutinized further for their specific and non-specific parameters to ensure their quality as Scientific Jamu.

\section{REFERENCES}

Amessis-Ouchemoukh, N., Madani, K., Falé, PLV., Serralheiro, ML., Araújo, MEM., 2014, Antioxidant capacity and phenolic contents 
of some Mediterranean medicinal plants and their potential role in the inhibition of cyclooxygenase- 1 and acetylcholinesterase activities, Industrial Crops and Products. 53(0):6-15.

Bagalkotkar, G., Sagineedu, S., Saad, M., Stanslas, J., 2006, Phytochemicals from Phyllanthus niruri Linn. and their pharmacological properties: a review, Journal of Pharmacy and Pharmacology. 58(12):1559-70.

DEPKES RI, 2008, Farmakope Herbal Indonesia Edisi I. Departemen Kesehatan Republik Indonesia, Jakarta

DEPKES RI, 2000, Parameter standar umum ekstrak tumbuhan obat. Departemen Kesehatan Republik Indonesia, Jakarta

http://materiamedicabatu.jatimprov.go.id/ (accessed on April 1, 2020)

http://www.b2p2toot.litbang.kemkes.go.id/ (accessed on April 1, 2020)

https://ipb.ac.id/page/research/biopharmaca/ (accessed on April 1, 2020)

Jayani, NIE., Kartini., Putri, LK., 2020, Standardization of a Crude Drug Moringa oleifera Leaf from Africa, India and Local (Indonesian) which Cultivated in Bojonegoro Indonesia, International Journal of Pharmaceutical Research. 12 (2).

Krisyanella, K., Susilawati, N., Rivai, H., 2017, Pembuatan Dan Karakterisasi Serta Penentuan Kadar Flavonoid Dari Ekstrak Kering Herba Meniran (Phyllanthus niruri L.), Jurnal Farmasi Higea. 5(1):9-19.

Kumar, S., Pandey, AK., 2013, Chemistry and biological activities of flavonoids: an overview, The Scientific World Journal, 2013: 1-15
MENKES RI, 2010, Peraturan Menteri Kesehatan Republik Indonesia Nomor 003. MENKES/PER/2010 tentang saintifikasi jamu dalam penelitian berbasis pelayanan kesehatan. Menteri Kesehatan Republik Indonesia, Jakarta

MENKES RI, 2013, Peraturan Menteri Kesehatan Republik Indonesia Nomor 82 Tahun 2013. Menteri Kesehatan Republik Indonesia, Jakarta

Purwadianto, A., Poerwaningsih, E., Widiyastuti, Y., Neilwan, A., Sukasediati, N., 2017, Pedoman Penelitian Jamu Berbasis Pelayanan Kesehatan. Lembaga Penerbit Badan Penelitian dan Pengembangan Kesehatan, Jakarta.

Seal, T., 2016, Quantitative HPLC analysis of phenolic acids, flavonoids and ascorbic acid in four different solvent extracts of two wild edible leaves, Sonchus arvensis and Oenanthe linearis of North-Eastern region in India, Journal of Applied Pharmaceutical Science, 6(2):157-66.

Tapas, AR., Sakarkar, D., Kakde, R., 2008, Flavonoids as nutraceuticals: a review, Tropical Journal of Pharmaceutical Research, 7(3):1089-99.

Triyono, A., 2016, Tujuh Ramuan Jamu Saintifik Pemanfaatan Mandiri Oleh Masyarakat, Lembaga Penerbit Badan Penelitian dan Pengembangan Kesehatan, Jakarta.

World Health Organization, 2011, Quality Control Methods for Herbal Materials. WHO Press, Geneva

Xia, Z., Liang, J., 2010, Steroids and phenols from Sonchus arvensis. Chinese Journal of Natural Medicines. 8(4):267-9. 